Website. http://hilirisasi.lppm.unand.ac.id

e-ISSN: 2621-7198

\title{
IMPLEMENTASI TEKNOLOGI WASTAFEL TANPA SENTUH DI RUMAH SAKIT KOTA PADANG DALAM RANGKA MEMUTUS MATA RANTAI COVID-19
}

\author{
Zaini $^{1 *)}$, Syarkawi Syamsuddin ${ }^{1)}$, Wisnu Joko Wulung ${ }^{1}$, Purnawan ${ }^{2}$, Hendery Dahlan ${ }^{3}$, \\ Wisnel $^{4}$, dan Denny Herald ${ }^{5}$ \\ 1) Jurusan Teknik Elektro, Fakultas Teknik Universitas Andalas \\ 2) Jurusan Teknik Sipil, Fakultas Teknik Universitas Andalas \\ 3) Jurusan Teknik Mesin, Fakultas Teknik Universitas Andalas \\ 4) Jurusan Teknik Industri, Fakultas Teknik Universitas Andalas \\ 5) Jurusan Teknik Lingkungan, Fakultas Teknik Universitas Andalas \\ *) Email : zzaini21@gmail.com
}

\begin{abstract}
ABSTRAK
Sikap kurang peduli masyarakat terhadap protokol kesehatan berbanding lurus dengan jumlah peningkatan masyarakat yang terdampak virus Covid-19. Kondisi ini semakin memburuk saat fasilitas umum seperti alat cuci tangan yang tersedia cenderung kurang higienis karena masih adanya kontak fisik selama proses pencucian tangan, sehingga memiliki potensi resiko yang besar untuk terjadinya penularan wabah Covid-19 di lingkungan masyarakat secara massal. Oleh karena itu dibuatlah sebuah inovasi berupa alat cuci tangan tanpa sentuh yang dilengkapi dengan sensor-sensor untuk menggantikan fungsi dari keran air dan wadah sabun cair manual. Khalayak sasaran dari kegiatan ini adalah masyarakat yang ada di lingkungan rumah sakit Kota Padang. Kegiatan ini dilaksanakan dalam dua tahap, yaitu tahap pertama untuk mendesain alat dan tahap kedua berupa pengadaan alat sekaligus sosialisasi kepada masyarakat Kota Padang yang berkunjung ke rumah sakit terkait pengenalan dan cara penggunaan alat cuci tangan tanpa sentuh sekaligus memperagakan kepada masyarakat dengan dibantu oleh pihak rumah sakit tentang cara cuci tangan yang baik dan benar sesuai protokol kesehatan.
\end{abstract}

Kata Kunci : Covid-19, disiplin protokol kesehatan, alat cuci tangan tanpa sentuh

\section{Implementation of Touching No-Touch Sink Technology in The City Hospital of Padang in Order to Disconnect Chain Covid-19}

\begin{abstract}
The public's lack of concern for health protocols is directly proportional to the increase in the number of people affected by the Covid-19 virus. This condition worsens when public facilities such as hand washing equipment available tend to be less hygienic because there is still physical contact during the hand washing process, so that it has a great potential risk of spreading the Covid-19 outbreak in the community on a large scale. Therefore an innovation was made in the form of a touchless hand washing device equipped with sensors to replace the function of the water tap and manual liquid soap container. The target audience of this activity is the people in the hospital environment of Padang City. This activity is carried out in two stages, namely the first stage to design tools and the second stage in the form of procurement of tools as well as outreach to the people of Padang City who visit the hospital regarding the introduction and how to use hand washing tools without touch as well as demonstrating to the community with the assistance of the hospital about how to wash hands properly and correctly according to health protocols.
\end{abstract}

Keywords: Covid-19, health protocol discipline, touchless hand washing tools 


\section{PENDAHULUAN}

Epidemiolog Universitas Indonesia Pandu Riono menyebutkan bahwa Pembatasan Sosial Berskala Besar (PSBB) sangat efektif dilakukan untuk pengendalian pandemi Covid-19 dalam skala nasional (Dinisari, 2020). Akan tetapi, solusi ini tidak baik pada sektor perekonomian jika dilakukan dalam jangka waktu yang panjang, Sehingga sudah sewajarnya bila new normal menjadi jalan tengah yang cukup baik untuk dilakukan di masa pandemi ini.

New normal atau tatanan hidup baru dinilai efektif untuk beradaptasi dengan Covid-19 dikarenakan mampu mewadahi masyarakat untuk bisa tetap produktif di luar rumah, akan tetapi hal ini seringkali dianggap sebagai suatu bentuk kebebesan oleh sebagian besar masyarakat pasca PSBB, sehingga terabaikannya protokol kesehatan dan turut berdampak terhadap meningkatnya kasus positif Covid-19. Achmad Yurianto sebagai juru bicara pemerintah untuk penanganan Covid-19 menegaskan bahwa "peningkatan kasus Covid-19 terjadi lantaran masih banyak warga yang belum disiplin melaksanakan protokol kesehatan" (Saputra, 2020). Untuk Terwujudnya sikap disiplin akan protokol kesehatan di era new normal ini, salah satunya dalam bentuk budaya cuci tangan sebelum dan sesudah beraktivitas maka dosen dan mahasiswa Jurusan Teknik Elektro berinovasi untuk membuat alat cuci tangan tanpa sentuh.

Adapun tujuan dari kegiatan program pengabdian kepada masyarakat ini, yaitu : 1. Sebagai sarana untuk mensosialisasikan teknologi berupa alat cuci tangan tanpa sentuh, dalam hal ini untuk mengurangi kecemasan masyarakat berupa kontak fisik langsung sewaktu mencuci tangan di tempat umum sebagaimana pada fasilitas cuci tangan konvensional, 2. Sebagai sarana untuk meningkatkan kesadaran dan menimbulkan kegemaran masyarakat dalam membudayakan hidup bersih dalam bentuk aktivitas cuci tangan guna meminimalisir penyebaran virus Covid-19, dan 3. Adanya transfer teknologi pada masyarakat (Donard Games, 2020) yang memproduksi alat serupa sehingga dapat membantu masyarakat dalam membuka lapangan pekerjaan di masa yang sulit ini (Albar, 2020).

\section{METODOLOGI}

Kegiatan ini dilaksanakan sejak bulan April sampai Juli 2020 di beberapa Rumah Sakit yang ada di Kota Padang, Seperti RS. Universitas Andalas, RSJ. Prof Dr HB Saanin, RST. Dr Reksodiwiryo, dan RSI. Ibnu Sina. Kegiatan ini dilaksanakan dalam dua tahap, yaitu tahap pertama untuk mendesain alat dan tahap kedua berupa pengadaan alat sekaligus sosialisasi kepada masyarakat Kota Padang yang berkunjung ke rumah sakit.

Metode yang digunakan dalam pelaksanaan program pengabdian kepada masyarakat adalah dengan cara membuat dan mensosialisasikan inovasi alat cuci tangan tanpa sentuh guna membantu pemerintah dalam memutuskan mata rantai wabah Covid-19 di Kota Padang.

Berikut merupakan gambar desain kerangka alat cuci tangan tanpa sentuh yang telah dibuat, dimana inovasi ini dilengkapi dengan sensor dalam penggunanya 
untuk menggantikan fungsi keran air dan pengambilan sabun cair secara manual, sehingga masyarakat cukup mengarahkan tangannya ke atas sensor maka air bersih atau sabun cair akan mengalir secara otomatis, dan dengan demikian inovasi alat ini dapat membantu masyarakat untuk mengurangi titik sentuh atau kontak fisik selama proses pencuci tangan (higienis) di tempat umum guna mengurangi penyebaran wabah Covid19. Berdasarkan dokumen resmi Kementerian Kesehatan, seseorang dapat tertular COVID-19 jika menyentuh permukaan atau benda yang terkena droplet, kemudian menyentuh mulut, hidung atau mata (Derisma, 2020).

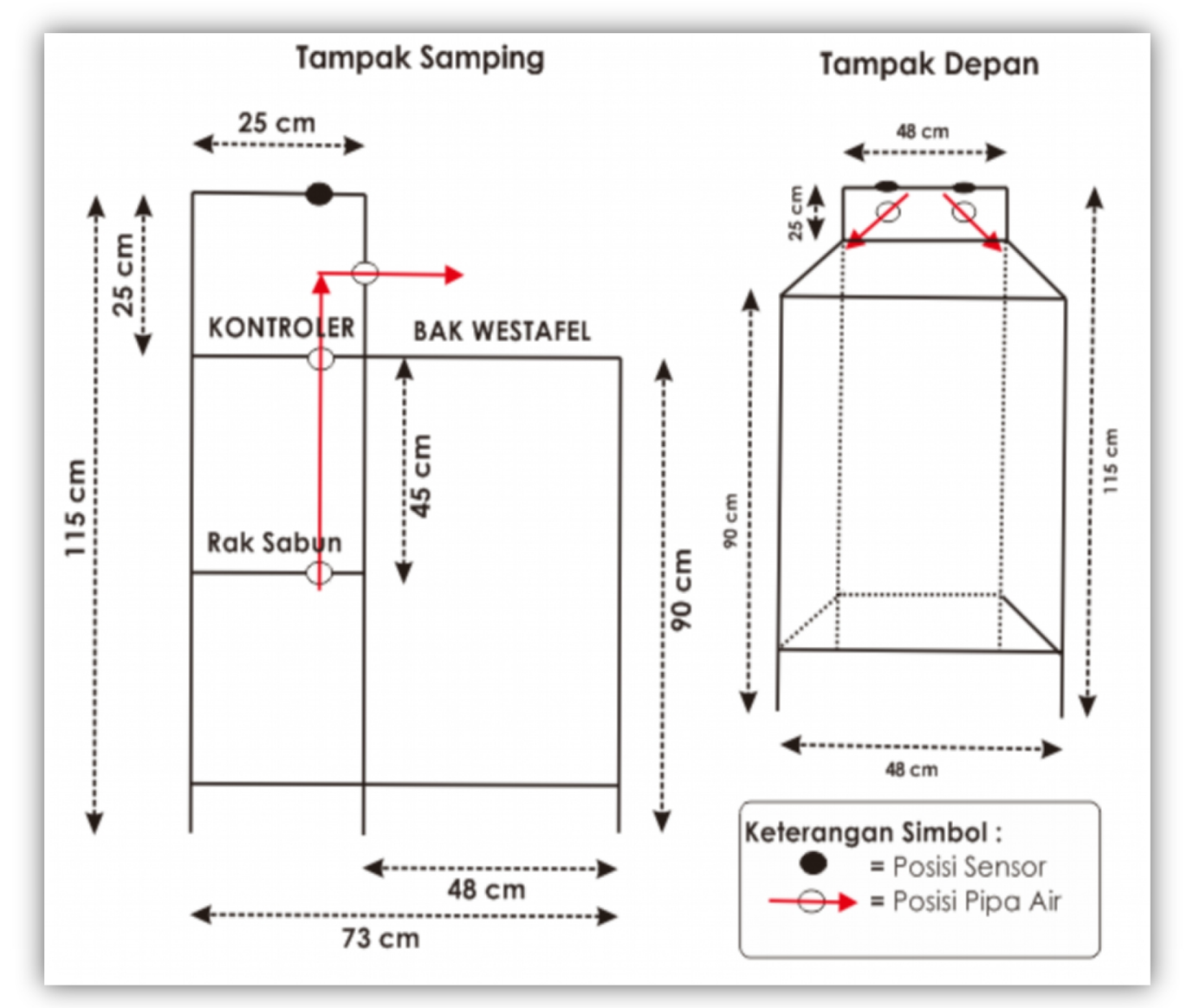

Gambar 1. Desain Alat Cuci Tangan Tanpa Sentuh

HASIL DAN PEMBAHASAN

Perancangan dan pengujian alat melibatkan mahasiswa, Selanjutnya untuk pembuatan kerangka alat cuci tangan tanpa sentuh dengan memberdayakan pengrajin besi yang terdampak Covid-19 di Kota Padang sehingga alat ini dapat tercipta (Oknovia Susanti, 2020).

Keunggulan dan kebaruan dari inovasi alat ini, yaitu menggunakan 2 buah sensor infrared proximity untuk menggantikan fungsi keran air dan wadah sabun yang rentan terhadap kontak fisik, serta memungkinkan terjadinya penyebaran virus Covid19 sebagaimana pada alat cuci tangan konvensional. Kemudian untuk suplai air pada alat ini juga dapat memanfaatkan air bersih yang telah tersedia oleh mesin pompa air 
Website. http://hilirisasi.lppm.unand.ac.id e-ISSN: 2621-7198

dari sumur atau PDAM, sehingga alat ini memberikan kemudahan dalam bentuk ketersediaan air bersih tanpa perlu mengisi ulang secara berkala, seperti hal nya pada toren air alat cuci tangan konvensional.

Selain itu, alat ini juga memiliki keunggulan lain dibandingkan dengan alat cuci tangan otomatis yang telah ada sebelumnya, dimana tidak hanya otomatis atau tanpa sentuh untuk mengalirkan air bersih, namun juga tanpa sentuh untuk mengalirkan sabun cair, atau dapat disimpulkan bahwa pada alat ini terdapat dua keran per-satu unit produk dengan fungsi yang berbeda, yaitu untuk air bersih dan sabun cair. Cara penggunaan dari inovasi alat cuci tangan tanpa sentuh ini dapat dilihat pada diagram alir berikut.

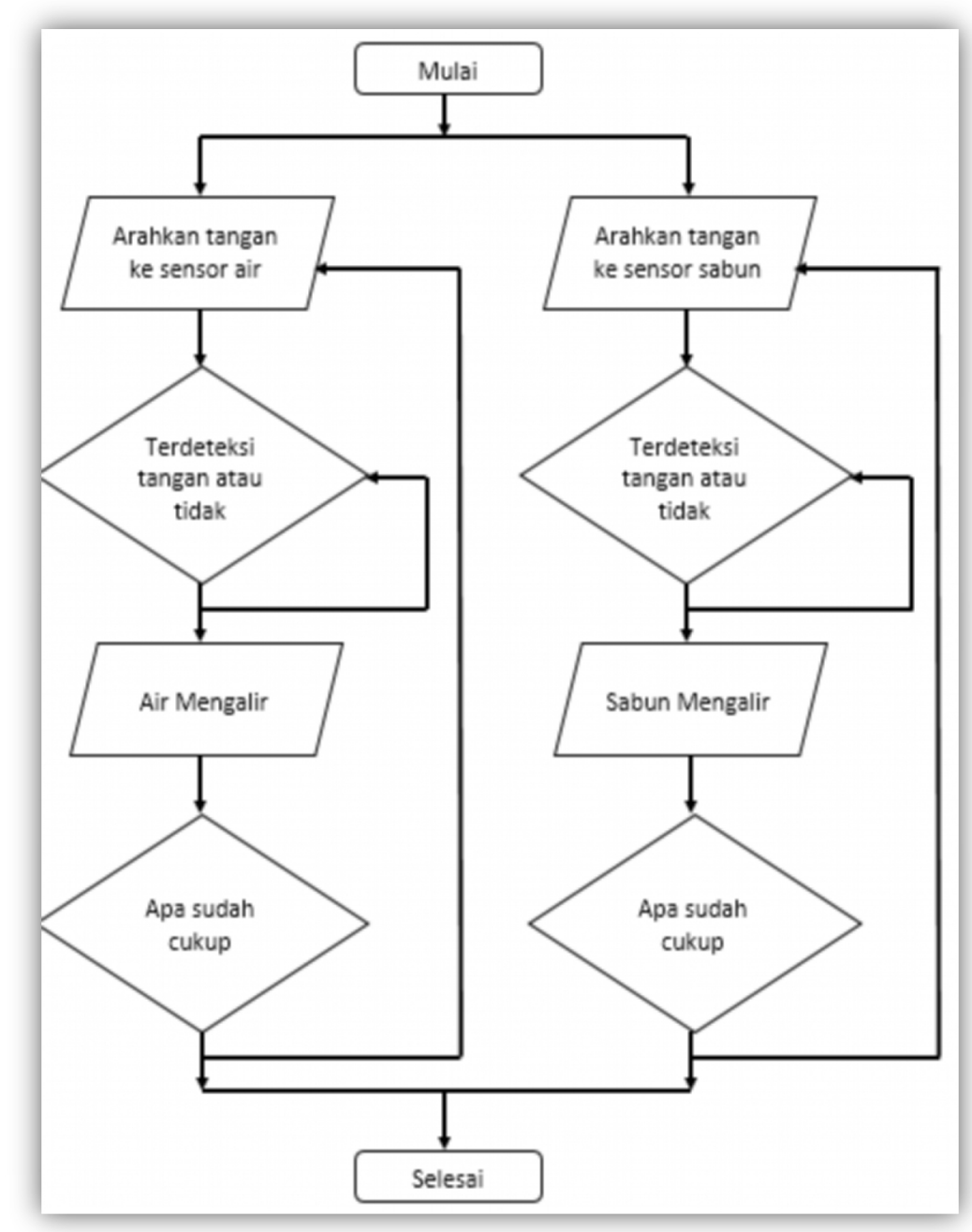

Gambar 2. Diagram Alir Penggunaan Alat

Dalam merealisasikan program kegiatan pengabdian masyarakat berjalan dengan baik dan tepat waktu sebagaimana arahan dari Fakultas Teknik Universitas Andalas. Hal ini dapat dilihat pada gambar berikut terkait pengadaan dan/atau penyerahan hasil inovasi dosen dan mahasiswa Jurusan Teknik Eektro Fakultas Teknik Universitas Andalas berupa satu unit alat cuci tangan tanpa sentuh pada beberapa rumah sakit yang ada di Kota padang. Selanjutnya, alat yang telah diserahkan langsung diperagakan kepada pihak rumah sakit (Helmizar1, 2020) untuk dapat disesuaikan 
Website. http://hilirisasi.lppm.unand.ac.id e-ISSN: 2621-7198

kondisi delay pada program yang telah tertanam di microkontroller alat cuci tangan tanpa sentuh dengan anjuran kesehatan di masa pandemi Covid-19 terkait berapa lamanya waktu yang dibutuhkan saat proses pencucian tangan, Setelah itu bersama pihak rumah sakit di lakukanlah sosialisasi kepada masyarakat terkait bagaimana cara penggunaan alat dan cuci tangan yang benar sesuai anjuran kesehatan.

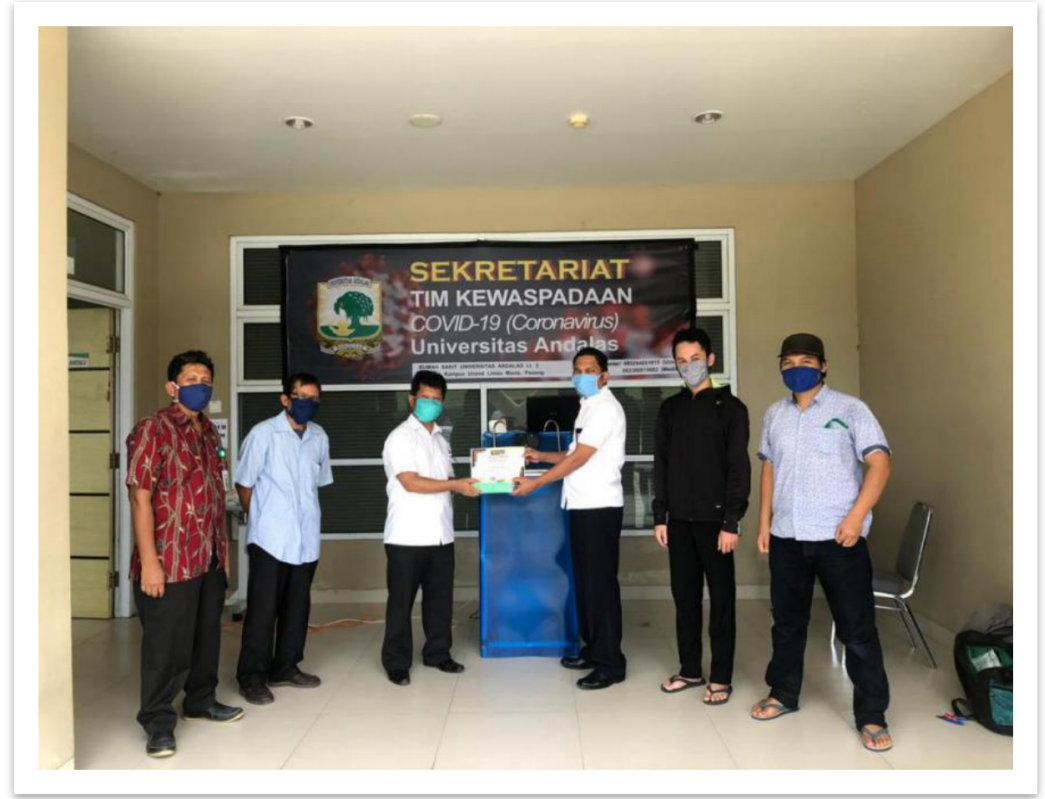

Gambar 3. Rumah Sakit Universitas Andalas

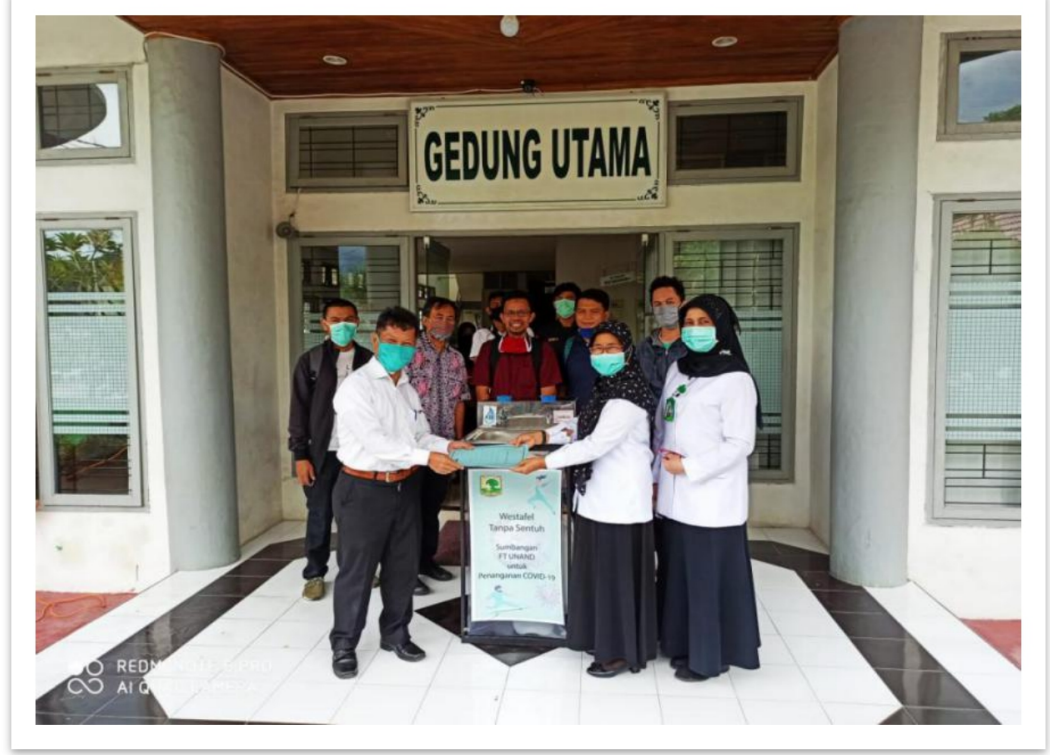

Gambar 4. Rumah Sakit Jiwa Prof Dr HB Saanin 
Website. http://hilirisasi.lppm.unand.ac.id e-ISSN: 2621-7198

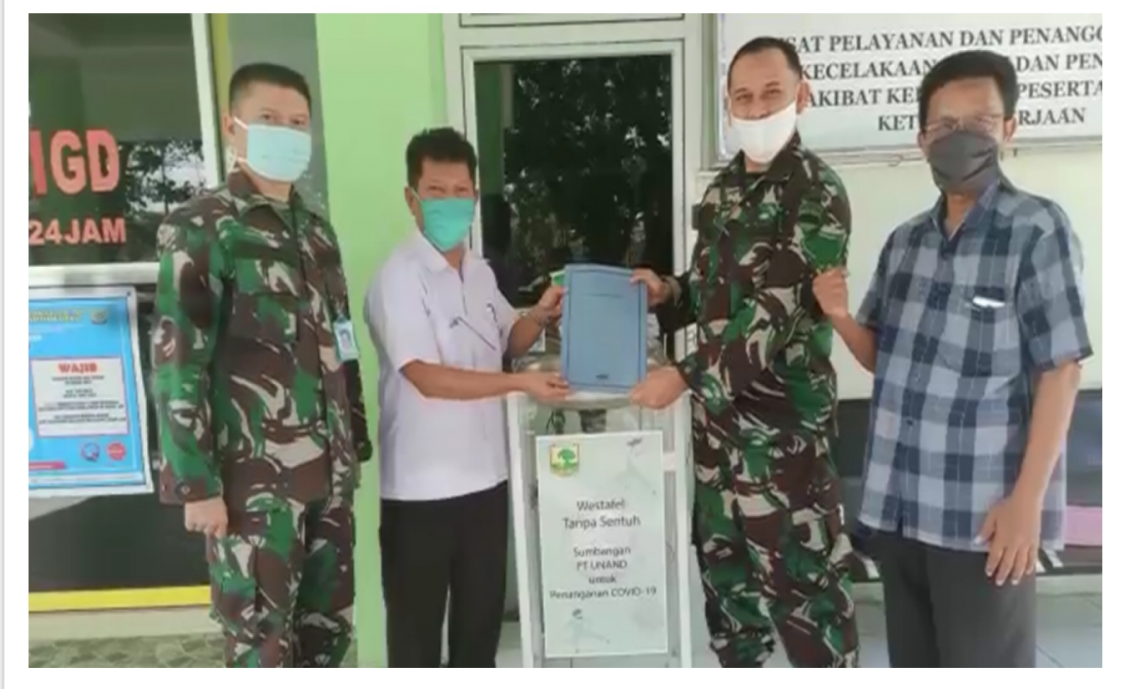

Gambar 5. Rumah Sakit Tentara Dr Reksodiwiryo

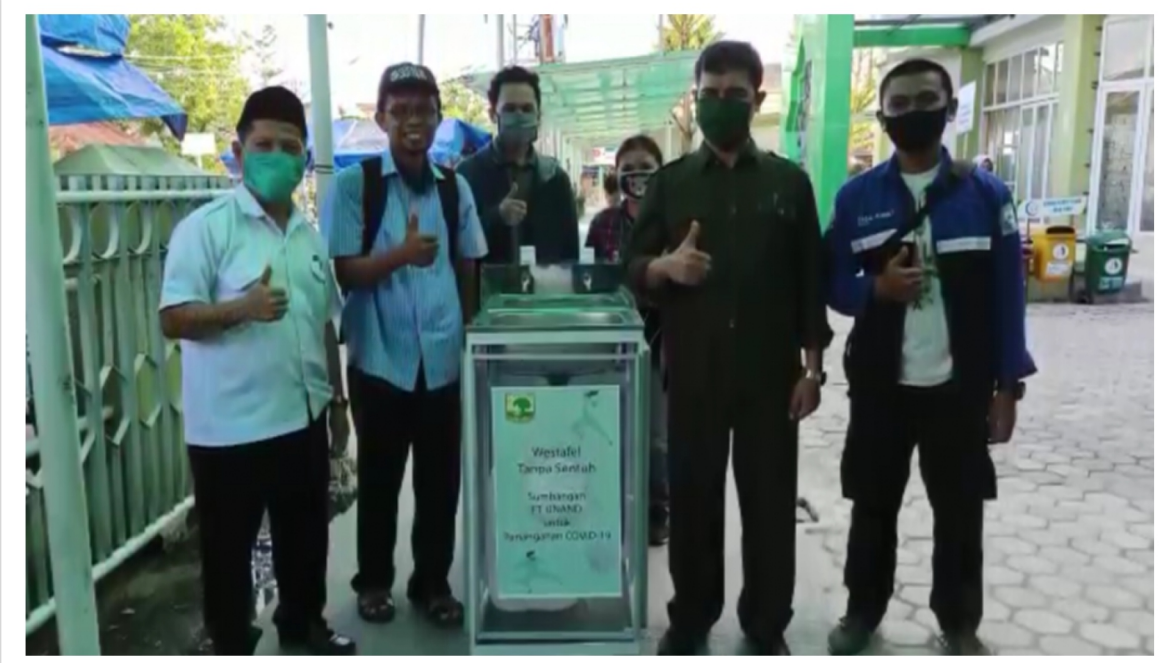

Gambar 6. Rumah Sakit Islam Ibnu Sina

\section{KESIMPULAN DAN SARAN}

Jurusan Teknik Elektro Fakultas Teknik Universitas Andalas telah membuat inovasi alat cuci tangan tanpa sentuh sebagai bentuk wujud pengabdian kepada masyarakat dalam membantu pemerintahan untuk mengendalikan penyebaran wabah Covid-19. Dengan adanya inovasi ini diharapkan mampu memberikan rasa aman dan nyaman kepada masyarakat saat mencuci tangan ditempat umum melalui keunggulan inovasi alat yang ditawarkan seperti terjaminnya kehigienisan selama proses pencucian tangan, hal ini dikarenakan pada alat telah dilengkapi dengan sensor untuk 
menggantikan fungsi keran layaknya pada fasilitas cuci tangan yang ada ditempat umum.

\section{UCAPAN TERIMAKASIH}

Penulis mengucapkan terima kasih kepada Prof. Gunawarman, Dr. Eng selaku Dekan Fakultas Teknik, Dr.-Ing. Ir. Uyung Gatot Syafrawi Dinata, M.T selaku Ketua LPPM dan Prof. Dr. Yuliandri, S.H., M.H selaku Rektor Universitas Andalas yang mendorong dosen untuk melakukan kegiatan ini dan mengarah pada penanggulangan penyebaran Corona Virus Disaese (Covid-19).

\section{DAFTAR PUSTAKA}

Berri Brilliant Albar. 2020. Ipteks berbasis inkubasi inovasi dan dunia usaha: market reserach produk-produk inovasi Universitas Andalas. Jurnal Hilirisasi Ipteks, 3(2), p. 131.

Derisma. 2020. Desain dan implementasi apd serta alat bantu pencegahan virus corona bagi tenaga kesehatan di Puskesmas Bungus Teluk Kabung Padang. Jurnal Hilirisasi Ipteks, Iii(2), p. 98.

Dinisari, Mia. $\quad$ C., $2020 . \quad$ Lifestyle. Available At:

Https://Lifestyle.Bisnis.Com/Read/20200910/106/1289645/Epidemiolog-

Sebut-Butuh-Psbb-Nasional-Untuk-Tekan-Kasus-Covid-19 [Diakses 9 September 2020].

Donard Games, dan Amri. S. 2020. Peningkatan produk berbasis inovasi Universitas Andalas : suatu strategi inkubasi bisnis. Jurnal Hilirisasi Ipteks, Iii(1), Pp. 4849.

Helmizar. 2020. Penanggulangan gizi buruk pada dokter dan petugas gizi Puskesmas di Dinas Kesehatan Kabupaten Tanah Datar. Jurnal Hilirisasi Ipteks, 3(2), Pp. 183-184.

Oknovia Susanti, Bima. S. A. 2020. Perancangan dan pembuatan mesin pemotong padi sederhana di Desa Pitalah Kabupaten Tanah Datar. Jurnal Hilirisasi Ipteks, 3(2), Pp. 150-152.

Saputra, A. 2020. Gridhealth. [Online] Available At: Https://Health.Grid.Id/Read/352222526/Kasus-Positif-CovidJustru-Meningkat-Saat-New-Normal-Pemerintah-UngkapPenyebabnya?Page=All [Diakses 9 September 2020]. 